\title{
HDL-Associated Paraoxonase 1 \\ Gene Polymorphisms as a Genetic Markers for Wide Spread Diseases
}

Ivana Pejin-Grubiša

Additional information is available at the end of the chapter

http://dx.doi.org/10.5772/48104

\section{Introduction}

The story of paraoxonase 1 (PON1) begins in 1946, when Abraham Mazur reported the presence of an enzyme in human and rabbit tissues which was able to hydrolyse organophosphate compounds [1]. In 1950s, enzyme was named "paraoxonase" according to its ability to hydrolyse paraoxon, the toxic metabolite of the organophosphate insecticide parathion [2,3]. Later it was discovered that it exhibits a broad spectrum of activities and has diverse substrates. Mackness and colleagues linked PON1 to cardiovascular diseases in 1991 and demonstrated that PON1 could prevent the accumulation of oxidized lipids in lowdensity lipoprotein (LDL) [4]. However, despite intensive research over sixty years the exact physiological function of PON1 is still unclear.

\section{Body}

\subsection{Paraoxonase 1}

The paraoxonase (PON) family of the enzymes consists of three members, PON1, PON2 and PON3 that share approximately $65 \%$ similarity at the amino acid level. These were named in order of their discovery, but according to the structural homology and predicted evolutionary distance between them it seems that PON2 is the oldest and PON1 is the youngest family member [5].

PON1 and PON3 enzymes are secreted from liver cells and associate with HDL in the circulation [6]. Low levels of PON1 may be expressed in a number of tissues, primarily in epithelia. PON2 in humans is more widely expressed and is found in nearly every human tissue including heart, kidney, liver, lung, placenta, small intestine, spleen stomach, testis [6- 
8]. Also, human PON2 mRNA is detected in the cells of the artery wall, including endothelial cells, smooth muscle cells and macrophages and is undetectable in HDL, LDL or the media of cultured cells $[6,7]$. Of the three PON proteins, PON3 is the most recently identified and the least characterized.

PON1 is the most studied and best understood. This calcium-dependent esterase is consisting of 354 amino acids with a molecular mass od approximately $45 \mathrm{kDa}[9,10]$ and requires calcium ions for structural stability and enzymatic activities [11]. It is capable of hydrolyzing organophosphates such as oxon metabolites of a insecticides parathion, diazinon and chlorpyrihos and nerve agents sarin and soman, aromatic esters such is phenyl acetate (arylesterase activity) and a variety of aromatic and aliphatic lactones (lactonase activity) [12-18]. Beside its protective role against dietary and environmental lactones, PON1 also catalyzes the reaction of lactonization of $\gamma$ - and $\delta$-hydroxycarboxylic acids [18]. It is capable of hydrolyse the oxidised lipid derivates 5-hydroxyeicosatetraenoic acid lactone acid (5-HETEL) and 4-hydroxy-docosahexaeonic acid (4HDoHE) which are potent triggers of an inflammatory response and therefore determinants of atherosclerotic disease [16,19].

\subsection{Paraoxonase 1 gene polymorphisms}

Genes that code for three PON proteins (pon1, pon 2 and pon3) are located to each other on the long arm of chromosome 7 in humans (7q21.3-22.1) and share approximately 70\% similarity at the nucleotide level [8]. Earlier studies on different human populations showed that the hydrolytic activity of serum PON1 was polymorphically distributed [20-22] and a number of research demonstrated that the molecular basis of these differences were Q192R, L55M and $\mathrm{C}(-107) \mathrm{T}$ polymorphisms in pon1 gene.

The pon 1 gene contains functional polymorphisms in both the coding and promoter regions. In the coding region, two common polymorphism are a glutamine $(\mathrm{Q})$ to arginine $(\mathrm{R})$ substitution at codon 192 (Q192R) and a leucine (L) to methionine (M) substitution at position 55 (L55M). In Q192R polymorphism the exchange of codon CAA to CGA in exon 6 of pon 1 gene determines isoforms of the enzyme which differ greatly in the rate of hydrolysis a number of substrates. Paraoxon is hydrolysed at a far greater rate by the R192 isoform compared to the Q192, but some organophospates and lactones are hydrolyzed faster by Q192 [12,13]. Recent study showed that R isoform of the enzyme has higher lactonase activity and increased antiatherogenic potential [23].

L55M polymorphism (exchange of codon TTG to ATG in exon 3) is correlated with blood enzyme level with isoform L55 associated with higher serum enzymatic activity. Still, it is not clear whether this is because of a decreased stability of the M55 alloenzyme [24] and/or because of the linkage disequilibrium with -107/-108 T allele [25, 26]. Isoform M55 showed lower stability and loses activity more rapidly and to a greater extent than the $\mathrm{L}$ isoform [24]. This is due to the key role of L55 in packing in the propeller's central tunnel, and of its neighboring residues which ligate calcium iones [27]. 
At least five polymorphisms have been detected in the human pon1 gene promoter region: C(-107/-108)T, G(-126)C, G(-162)A, G(-832)A and G(-909)C, but only C(-107T) apear to affects expression level of PON1 enzyme [25,26]. This single nucleotide polymorphism (SNP) is within stimulating protein-1 (Sp1) binding site with allele $\mathrm{T}$ that disrupts the recognition sequence for Sp1 and results in decreased affinity for it [28].

The frequencies of alleles of Q192R, L55M and C(-107)T polymorphisms are different among populations worldwide (Table 1). Data for European population showed predominance of Q192 and -107C alleles over R192 and -107T alleles. Spanish and Serbian populations showed higher frequency of the $-107 \mathrm{~T}$ allele. For codon 55 polymorphism, populations worldwide show predominance of L55 over M55 allele. In Asia allele Q192 is more frequent only in Indian Punjabis and Iranians and allele $-107 \mathrm{C}$ is predominant among examined populations. Afro-Americans and Amerindian tribes showed higher frequency of allele $\mathrm{R}$ compared with allele $\mathrm{Q}$ and predominance of allele-107C. Only Mexicans showed higher frequency of $-107 \mathrm{~T}$ allele. There is a very little data from "black“ continent and it concerns only Q192R polymorphism frequency with higher frequency of allele R only in Beninese (Table 1).

More than 200 single nucleotide polymorphisms (SNPs) have been identified in the human pon 1 gene but only these three have been associated with a number of pathophysiological conditions.

\subsection{Pon 1 variants and oxidative stress-related disorders}

The central role of HDL is in the process of reverse cholesterol transport (RHC). Also it has antioxidative, antiinflammatory and antifibrinolytic functions that contribute to its antiatherosclerotic effects. Mackness and coworkers were the first that showed that HDL acted at a specific point in the oxidation cascade: it metabolises oxidized phospholipids on LDL [29]. Although several other HDL-associated proteins such as apo AI, lecithin:cholesterol acyltransferase (LCAT) and platelet-activating factor acetyltransferase (PAFAH) also have antioxidant properties, PON1 seems to be the predominant antioxidant enzyme [4, 29-31]. HDL isolated from the blood of PON1 knock-out mice or from avian species which naturally lack PON1, has at best, no effect on LDL-oxidation and at worst promotes LDL-oxidation [32,33]. Conversely, HDL isolated from mice overexpressing human PON1 completely abolishes LDL-oxidation [34]. Several human studies have shown an inverse linear relationship between the concentration of oxidised-LDL in the circulation and PON1 activity, strongly implicating PON1 in the metabolism of oxidised-LDL in vivo $[35,36]$.

Enzymatic and nonenzymatic systems of antioxidative protection are included in scavenging free radicals and their metabolic products and in maintaining normal cellular physiology. Increased level of free radicals and impairment of antioxidant status are processes underlying pathophysiologic mechanisms in a variety of diseases including 
atherosclerosis, diabetes mellitus, cancer, chronic liver impairment, several neurological diseases, many infectious diseases and association studies have identified links between pon1 gene polymorphisms and susceptibility and outcome of these diseases.

\begin{tabular}{|c|c|c|c|c|c|c|c|}
\hline \multirow{2}{*}{$\begin{array}{c}\text { pon1 } \\
\text { polymorphisms }\end{array}$} & \multicolumn{2}{|c|}{ Q192R } & \multicolumn{2}{|c|}{ L55M } & \multicolumn{2}{|c|}{$\mathrm{C}(-107) \mathrm{T}$} & \multirow[t]{2}{*}{ References } \\
\hline & $Q$ & $\mathbf{R}$ & $\mathbf{L}$ & $\mathbf{M}$ & C & $T$ & \\
\hline \multicolumn{8}{|c|}{ Populations of Europe } \\
\hline Finnish & 0.69 & 0.31 & 0.67 & 0.33 & - & - & 76 \\
\hline Dutch & 0.68 & 0.32 & 0.63 & 0.37 & - & - & 77 \\
\hline Spanish & 0.7 & 0.3 & 0.63 & 0.37 & 0.46 & 0.54 & 78 \\
\hline Italians & 0.65 & 0.35 & 0.66 & 0.34 & 0.57 & 0.43 & 79 \\
\hline English & 0.78 & 0.22 & 0.7 & 0.3 & 0.52 & 0.48 & 80 \\
\hline Turkish & 0.69 & 0.31 & 0.7 & 0.3 & - & - & 81 \\
\hline Croatian & 0.77 & 0.23 & 0.66 & 0.34 & 0.54 & 0.46 & 82 \\
\hline Czecs & 0.54 & 0.46 & 0.69 & 0.31 & 0.59 & 0.41 & 83 \\
\hline Serbian & 0.77 & 0.23 & 0.68 & 0.32 & - & - & 84 \\
\hline \multicolumn{8}{|l|}{ Populations of Asia } \\
\hline $\begin{array}{l}\text { Asian Indians } \\
\text { Punjabis }\end{array}$ & 0.74 & 0.26 & 0.81 & 0.19 & 0.52 & 0.48 & 85 \\
\hline Japanese & 0.4 & 0.6 & 0.94 & 0.06 & 0.48 & 0.52 & 86 \\
\hline Koreans & 0.38 & 0.620 & 0.94 & 0.06 & - & - & 87 \\
\hline Chinese & 0.42 & 0.58 & 0.95 & 0.05 & 0.57 & 0.43 & 88,89 \\
\hline Iranian & 0.69 & 0.31 & 0.59 & 0.41 & - & - & 90 \\
\hline \multicolumn{8}{|c|}{ Populations of America } \\
\hline $\begin{array}{l}\text { Caucasian- } \\
\text { Americans }\end{array}$ & 0.73 & 0.27 & 0.64 & 0.36 & 0.5 & 0.5 & 26 \\
\hline Canadians & 0.73 & 0.27 & 0.64 & 0.36 & 0.48 & 0.52 & 91,28 \\
\hline $\begin{array}{c}\text { African- } \\
\text { Americans } \\
\end{array}$ & 0.37 & 0.63 & 0.79 & 0.21 & 0.85 & 0.15 & 92 \\
\hline $\begin{array}{c}\text { Amazonian } \\
\text { Amerindian } \\
\text { tribes }\end{array}$ & 0.27 & 0.730 & 0.967 & 0.033 & - & - & 93 \\
\hline $\begin{array}{l}\text { Caribean- } \\
\text { Hispanics } \\
\end{array}$ & 0.540 & 0.460 & 0.71 & 0.29 & 0.65 & 0.35 & 92 \\
\hline Mexicans & 0.510 & 0.490 & 0.84 & 0.16 & 0.45 & 0.55 & 94 \\
\hline Peruvians & 0.539 & 0.461 & - & - & 0.61 & 0.39 & 95 \\
\hline \multicolumn{8}{|c|}{ Populations of Africa } \\
\hline Beninese & 0.388 & 0.612 & - & - & - & - & 96 \\
\hline Ethiopians & 0.592 & 0.408 & - & - & - & - & 96 \\
\hline Egyptians & 0.67 & 0.33 & - & - & - & - & 97 \\
\hline
\end{tabular}

Table 1. The allele frequencies of pon1 gene polymorphisms Q192R, L55M and C(-107)T in populations worldwide 
According to World Health Organization (WHO data for 2010), 95\% of mortality in Serbia is caused by chronic noncontagious diseases, wherefrom $58 \%$ of it is caused by cardiovascular diseases (CVD) [37]. Although patients with CVD commonly have at least one identifiable risk factor, many ischemic events occur in the absence of any of it [38]. Atherogenesis, one of the main risk factors for CVD, is initiated by oxidation of the low-density lipoprotein (LDL) and by impairment in oxidative stress-antioxidant balance.

Enhanced oxidative stress such as in diabetes, leads to the development of accelerated atherosclerosis. Atherosclerosis in patients with diabetes tends to occur earlier and be more aggressive. People with type 2 diabetes have a 3-4 fold increased risk of developing atherosclerosis compared to people without type 2 diabetes. Serbia falls into the group of European countries with the highest diabetes mortality rates where diabetes is the fifth leading cause of death and the fifth cause of the burden of disease [39]. At least a half of the persons with non-insulin dependent diabetes mellitus (NIDDM) have not been diagnosed and are not aware of their disease [40,41].

Due to the abovementioned, there has been a marked interest in discovering additional markers of oxidative stress, including gene variants, which may have a role in predicting wide spread diseases risk. Because controversial results have been reported so far, the aim of studies performed in our laboratory was to evaluate possible interactions between pon 1 gene polymorphisms and clinical manifestations of atherosclerosis and diabetes mellitus type 2 in our population.

Allele and genotype frequencies for Q192R, L55M and C(-107)T did not show significant difference between cases with clinical manifestations of atherosclerosis (60 subjects) and controls (100 subjects) $(\mathrm{P}>0.05)$. Although the $\mathrm{M}$ allele (L55M) has shown a somewhat higher risk $(\mathrm{OR}=1.23)$ and the $\mathrm{T}$ allele $(-107 \mathrm{C} / \mathrm{T})$ has shown a 1.49 times lower risk of occurence of the disease $(\mathrm{OR}=0.67)$ the difference did not reach statistical significance, most likely due to low number of subjects (Grubisa et al., unpublished data).

Also, we investigated the association between these polymorphisms and atherosclerosis in patients with type 2 diabetes mellitus (140 subjects). Our results have shown that $\mathrm{R}$ allele is a risk factor for atherosclerosis in these patients $(\mathrm{OR}=2.22, \mathrm{P}<0.0001)$. Although $\mathrm{M}$ allele has shown a little higher risk $(\mathrm{OR}=1.26)$ and allele $\mathrm{T}$ has shown a slightly lower risk $(\mathrm{OR}=0.85)$ the results obtained do not support an association between these pon 1 gene variants and atherosclerosis in NIDDM patients (Grubisa et al., unpublished data).

Lactones are hydrolyzed preferentially by either PON1 Q or R isoformes, depending of their structure. R192 is more efficient at hydrolyzing homocysteine thiolactone, while $\delta$ valerolactone and 2-coumaranone are more rapidly hydrolyzed by PON1Q192 [12]. In 1990 's the results obtained indicated that the Q192R polymorphism may play the role in coronay heart disease (CHD) etiology because this genotype is associated with LDL oxidation; the PON1-192 R isoform is less effective at hydrolysing lipid peroxides than the $\mathrm{Q}$ isoform [42,43]. It have been shown that position 192 is involved in HDL binding as a part of amphipathic helix $\mathrm{H} 2$ of active site [27]. Gaidukov and coworkers reported from in 
vitro and sera tests that the PON1-192Q izoform binds HDL with a 3-fold lower affinity than the $\mathrm{R}$ isozyme and consequently exhibits significantly reduced stability, lipolactonase activity, and macrophage cholesterol efflux [27]. The higher lactonase activity is manifested by increased antiatherogenic potency: the observed rate of HDLmediated cholesterol efflux from macrophages is 2.2-fold higher for the 192R [27]. Also it was shown that the affinity and stability of the PON1 on HDL was lower in sera of individuals with the Q192 variant than in individuals with the 192R variant [27]. Low levels of HDL particles is one of the strongest risk factors for coronary heart disease and one of the characteristic features of diabetic dyslipidemia and it seems that proteins on HDL play a major role in the protection against atherosclerois-based cardiovascular diseases. HDL carryng apolipoprotein A-I binds PON1 with high affinity, stabilizes the enzyme and stimulates its lipolactonase activity [44].

PON1 is also an extracellular homocysteine-thiolactonase (Hcy-thiolactonase). Hcythiolactone is a toxic metabolite linked to immune activation and thrombogenesis in human cardiovascular diseases and is elevated under conditions predisposing atherosclerosis [4547]. A small fraction of Hcy, a sulfur-containing amino acid, is metabolized to a Hcythiolactone in an error-editing reaction in protein biosynthesis when Hcy is mistakenly selected instead of dietary methonine (Met) [48]. Hcy-thiolactone is neutral at physiological $\mathrm{pH}$ and can diffuse out of the cell and accumulate in the extracellular fluids where is hydrolyzed to Hcy by extracellular Hcy-thiolactonase-paraoxonase 1 [49]

Hcy-thiolactonase activity is strongly associated with pon1 genotype in diverse human populations [15]. High Hcy-thiolactonase activity is associated with L55 and R192 alleles, more frequent in blacks than in whites and low activity is associated with M55 and Q192 alleles, more frequent in whites than in blacks [15]. Despite the impact of pon1 genotype on Hcy-thiolactonase activity, these genetic variations are not asociated with atherosclerosisbased cardiovascular diseases. It seems that PON1 phenotype is better predictor $[16,50]$.

Human clinical studies suggest that PON1 phenotype, i.e., paraoxonase activity is a much stronger predictor of cardiovascular disease status than PON1 genetic polymorphisms [51$55]$ a finding that has been confirmed in other studies [52,55]. Bhattacharyya and colleagues demonstrated that both the pon1 Q192R polymorphism and serum PON1 activity are associated with prevalent coronary artery disease and incident adverse cardiovascular events [56]. This study complemented the study of Gaidukov, demonstrating that individuals with the arginine (R) at position 192 have higher serum levels of PON1 activity, lower systemic indices of systemic oxidative stress and corresponding reductions in both prevalent coronary artery disease and prospective cardiac events [56]. Plasma PON1 activity can vary up to 40 to 50-fold, and differences in PON1 protein levels up to 13-15-fold are also present within a single PON1 Q192R genotype in adults [57,58]. A number of studies indicated that measurement of an individual's PON1 function (serum activity) takes into account all polymorphism and other factors that might affect PON1 activity or expression. However, modulation of PON1 by alcohol, smoking, drugs, diet, certain physiological and pathological conditions should also be considered. These factors can increase or decrease PON1 activity [59] as well as HDL status. 
However, PON1 activity is partially inactivated during the detoxification of lipid hydroperoxides [60]. This effect can be possibly related to displacement of calcium ions or inhibition through free radicals directly. It has been suggested that other antioxidant enzymes might prevent this inhibition of PON1 activity. Antioxidant enzymes, all show coactivity and might work in a collaboration against oxidative stress and elevation in oxidative stress might inhibit these enzymes [61].

Paraoxonases are important detoxifying and anti-oxidative enzymes, which establishes their role in organophosphate poisoning, diabetes, obesity, cardiovascular diseases, and innate immunity $[62,63]$ Consequently, PON2 has been the focus of a great deal of research in recent years. Both PON1 and PON2 protect against atherosclerosis development and share ability to hydrolyze lactones with both overlaping and distinct substrate specificities [19]. Although PON1 is associated with circulating serum HDL and reduces oxidative stress in lipoproteins, macrophages in arterial walls and in atherosclerotic lesion by its ability to hydrolyze specific oxidized lipids, PON2 acts as an intracelullar antioxidant [7,64-68] associated with plasma membrane [6-8]. The mechanism how PON2 modulates oxidative stress is still unknown, although Altenhöfer demonstrated that PON2 prevents superoxide generation, but was ineffective against existing radicals [69]. Oxidative stress affects PON2 expression too, but additional studies are needed to highlight the PON2 expression level under oxidative stress since controversial results both from in vivo and in vitro experiments have been reported $[6,7,66,70-74]$.

\section{Conclusion}

Paraoxonase 1 is found to be associated with HDL particles within circulation and therefore promotes some of HDL's functions. There is no consistent evidence for involvement of pon1 genotypes in atherosclerosis and diabetes mellitus type 2. Studies analyzed the role of pon1 polymorphisms in oxidative stress-based diseases showed a great variation in ethnics, environmental background, age and gender of case and control groups. Allele frequencies appeared to be dependent on geographic locations, perhaps also due to genetic drift. Probably the effect of each polymorphism alone of he so called oxidative stress-associated genes is not strong enough to affect initiation and progression of atherosclerosis as well as PON1 enzyme status (activity levels and catalytic efficiency specified by the Q192R polymorphism) [75].

\section{Author details}

Ivana Pejin-Grubiša

Department of Human Genetics and Prenatal Diagnostics, Zvezdara University Medical Center, Belgrade, Serbia

\section{References}

[1] Mazur A (1946) An Enzyme in Animal Tissue Capable of Hydrolyzing the Phosphorusfluorine Bond of Alkyl Fluorophosphates. J. Biol. Chem. 164:271-289. 
[2] Aldridge WN (1953a) Serum Esterases I. Two Types of Esterase (A and B) Hydrolysing p-nitrophenyl Acetate, Propionate and Butyrate and a Method for Their Determination. Biochem. J. 53:110-117.

[3] Aldridge WN (1953b) Serum Esterases II. An Enzyme Hydrolysing Diethyl pnitrophenyl Acetate (E600) and Its Identity With the A-esterase of Mammalian Sera. Biochem. J. 53:117-124.

[4] Mackness M, Arrol S, Durrington PN (1991) Paraoxonase Prevents Accumulation of Lipoperoxides in Low-Density Lipoprotein. FEBS Lett. 286:152-154.

[5] Draganov DI, La Du BN (2004) Pharmacogenetics of Paraoxonses, a Brief Review. Naunyn-Schmiedeberg's Arch. Pharmacol. 369:78-88.

[6] Ng CJ, Shih DM, Hama SY, Villa B, Navab M, Reddy ST (2005) The Paraoxonase Gene Family and Atherosclerosis. Free Radic. Biol. Med. 38:153-163.

[7] Ng CJ, Wadleigh DJ, Gangopadhyay A, Hama S, Grijalva VR, Navab M, Fogelman AM, Reddy ST (2001) Paraoxonase-2 is a Ubiquitously Expressed Protein With Antioxidant Properties and is Capable of Preventing Cell-mediated Oxidative Modification of Low Density Lipoprotein. J. Biol. Chem. 276(48): 44444-44449.

[8] Primo-Parmo SL, Sorenson RC, Teiber J, La Du BN, (1996) The Human Serum Paraoxonase/Arylesterase Gene (PON1) is One Member of a Multigene Family. Genomics 33:498-507.

[9] Furlong CE, Richter RJ, Seidel SL, Costa LG, Motulsky AG (1989) Spectrophotometric Assays for the Enzymatic Hydrolysis of the Active Metabolites of Chlorpyrifos and Parathion by Plasma Paraoxonase/Arylesterase. Anal. Biochem. 180: 242-247.

[10] Hassett C, Richter RJ, Humbert R, Chapline C, Crabb JW, Omiecinski CJ, Furlong CE (1991) Characterization of cDNA Clones Encoding Rabbit and Human Serum Paraoxonase: the Mature Protein Retains its Signal Sequence. Biochemistry 30:1014110149.

[11] Kuo CL, La Du BN (1998) Calcium Binding by Human and Rabbit Serum Paraoxonases. Structural Stability and Enzymatic Activity. Drug Metab. Dispos. 26:653-660.

[12] Billecke S, Draganov D, Counsell R, Stetson P, Watson C, Hsu C, La Du BN (2000) Human Serum Paraoxonase (PON1) Isozymes $Q$ and R Hydrolyze Lactones and Cyclic Carbonate Esters. Drug Metab. Dispos. 28:1335-1342.

[13] Davies HG, Richter RJ, Keifer M, Broomfield CA, Sowalla J, and Furlong CE (1996) The Effect of the Human Serum Paraoxonase Polymorphism is Reversed With Diazoxon, Soman and Sarin. Nat. Genet. 14:334-336.

[14] Furlong CE, Li WF, Brophy VH, Jarvik GP, Richter RJ, Shih DM, Lusis AJ, Costa LG (2000) The PON1 Gene and Detoxication. Neurotoxicology 21:581-587.

[15] Jakubowski H, Ambrosius WT, Pratt JH (2001) Genetic Determinants of Homocysteine Thiolactonase Activity in Humans: Implications for Atherosclerosis. FEBS Lett. 491:3539.

[16] Khersonsky O, Tawfik DS (2005) Structure-Reactivity Studies of Serum Paraoxonase PON1 Suggest That its Native Activity is Lactonase. Biochemistry 44:6371-6382.

[17] Rodrigo L, Mackness B, Durrington PN, Hernandez A, Mackness MI (2001) Hydrolysis of Platelet-Activating Factor by Human Serum Paraoxonase. Biochem. J. 354:1-7. 
[18] Teiber JF, Draganov DI, La Du BN (2003) Lactonase and Lactonizing Activities of Human Serum Paraoxonase (PON1) and Rabbit Serum PON3. Biochem. Pharmacol. 66:887-896.

[19] Draganov DI, Teiber JF, Speelman A, Osawa Y, Sunahara R, La Du BN (2005) Human Paraoxonases (PON1, PON2, and PON3) are Lactonases With Overlapping and Distinct Substrate Specificities. J. Lipid Res. 46:1239-1247.

[20] Eckerson HW, Wyte CM, LaDu BN (1983) The Human Serum Paraoxonase/Arylesterase Polymorphism. Am. J. Hum. Genet. 35:1126-1138.

[21] Mueller RF, Hornung S, Furlong CE, Anderson J, Giblett ER, Motulsky AG (1983) Plasma Paraoxonase Polymorphism: a New Enzyme Assay, Population, Family Biochemical and Linkage Studies. Am. J. Hum. Genet. 35:393-408.

[22] Playfer JR, Eze LC, Bullen MF, Evans DA (1976) Genetic Polymorphism and Interethnic Variability of Plasma Paraoxonase Activity. J. Med. Genet. 13:337-342.

[23] Gaidukov L, Rosenblat M, Aviram M, Tawfik DS (2006) The 192R/Q Polymorphs of Serum Paraoxonase PON1 Differ in HDL Binding, Lipolactonase Stimulation, and Cholesterol Efflux: J. Lipid Res. 47:2492-2502.

[24] Leviev I, Deakin S, James RW (2001) Decreased Stability of the M54 Isoform of Paraoxonase as a Contributory Factor to Variations in Human Serum Paraoxonase Concentrations. J. Lipid Res. 42: 528-535.

[25] Leviev I, James RW (2000) Promoter Polymorphisms of Human Paraoxonase PON1 Gene and Serum Paraoxonase Activities and Concentrations. Arterioscler. Thromb.Vasc. Biol. 20:516-521.

[26] Brophy VH, Jampsa RL, Clendenning JB, McKinstry LA, Jarvik GP, Furlong CE (2001) Effects of 5' Regulatory-Region Polymorphisms on Paraoxonase-Gene (PON1) Expression. Am. J. Hum. Genet. 68:1428-1436.

[27] Harel M, Aharoni A, Gaidukov L, Brumshtein B, Khersonsky O, Meged R, Dvir H, Ravelli RBG, McCarthy A, Toker L, Silman I, Sussman JL, Tawfik DS (2004) Structure and Evolution of the Serum Paraoxonase Family of Detoxifying and AntiAtherosclerotic Enzymes. Nat. Struct. Mol. Biol. 11:412-419.

[28] Deakin S, Leviev I, Brulhart-Meynet MC, James RW (2003) Paraoxonase-1 Promoter Haplotypes and Serum Paraoxonase: a Predominant Role for Polymorphic Position 107, Implicating the Sp1 Transcription Factor. Biochem. J. 372:643-649.

[29] Mackness MI, Arrol S, Abbott CA, Durrington PN (1993) Protection of Low-Density Lipoprotein Against Oxidative Modification by High-Density Lipoprotein Associated Paraoxonase. Atherosclerosis. 104:129-135.

[30] Ahmed Z, Ravandi A, Maguire GF, Emili A, Draganov D, La Du BN, Kuksis A, Connelly PW (2001) Apolipoprotein AI Promotes the Formation of Phosphatidylcholine Core Aldehydes That are Hydrolysed by Paraoxonase (PON1) During High Density Lipoprotein Oxidation With a Peroxynitrite Donor. J. Biol. Chem. 276:24473-24481.

[31] Watson AD, Berliner JA, Hama SY, La Du BN, Fault KF, Fogelman AM, Navab M (1995) Protective Effect of High Density Lipoprotein Associated Paraoxonase-Inhibition of the Biological Activity of Minimally Oxidised Low-Density Lipoprotein. J. Clin. Invest. 96: 2882-2891. 
[32] Shih DM, Gu L, Xia YR, Navab M, Li WF, Hama S, Castellani LW, Furlong CE, Costa LG, Fogelman AM, Lusis AJ (1998) Mice Lacking Serum Paraoxonase are Susceptible to Organophosphate Toxicity and Atherosclerosis. Nature. 394:284-287.

[33] Mackness B, Mackness M.I, Arrol S, Turkie W, Durrington PN (1998). Effect of the Human Serum Paraoxonase 55 and 192 Genetic Polymorphisms on the Protection by High Density Lipoprotein Against Low Density Lipoprotein Oxidative Modification. FEBS Letts. 423:57-60.

[34] Tward A, Xia YR, Wang XP, Shi YS, Park C, Castellani LW, Lusis A, Shih DH (2002) Decreased Atherosclerotic Lesion Formation in Human Serum Paraoxonase Transgenic Mice. Circulation 106:484-490.

[35] Sampson MJ, Braschi S, Willis G, Astley SB (2005) Paraoxonase-1 (PON1) Genotype and Activity and in vivo Oxidised, Plasma Low-Density Lipoprotein in Type II Diabetes. Clin. Sci 109:189-197.

[36] Tsuzura S, Ikeda Y, Suehiro T, Ota K, Osaki F, Arii K, Kumon Y, Hashimoto K (2004) Correlation of Plasma Oxidized Low-Density Lipoprotein Levels to Vascular Complications and Human Serum Paraoxonase in Patients With Type 2 Diabetes. Metabolism 53:297-302.

[37] World Health Organization (WHO) (2011) Noncommunicable Diseases Country Profiles 2011. Available: http://www.who.int/nmh/publications/ncd_profiles2011/en/

[38] Futterman LG, Lemberg L (1998) Fifty Percent of Patients With Coronary Artery Disease Do Not Have Any of the Conventional Risk Factors. Am J Crit Care. 7:240-4.

[39] Incidence and Mortality of Diabetes in Serbia 2010. Serbian Diabetes Registry. Report No5. Institute of Public Health of Serbia „Dr Milan Jovanović Batut“ 2011.

[40] Ford ES (2005) Risks for All-Cause Mortality, Cardiovascular Disease, and Diabetes Associated With the Metabolic Syndrome: a Summary of the Evidence. Diabet. Care 28:1769-1778.

[41] McEwan P, Williams JE, Griffiths Bagust A, Peters JR, Hopkinson P, Currie CJ (2004) Evaluating the Performance of the Framingham Risk Equations in a Population With Diabetes. Diabet. Med. 21:318-323.

[42] Aviram M, Billecke S, Sorenson R, Bisgaier C, Newton R, Rosenblat M, Erogul J, Hsu C, Dunlop C, La Du BN (1998) Paraoxonase Active Site Required for Protection Against LDL Oxidation Involves its Free Sulphydryl Group and is Different From That Required for its Arylesterase/Paraoxonase Activities: Selective Action of Human Paraoxonase Alloenzymes Q and R. Arterioscl. Thromb. Vasc. Biol. 10:1617-1624.

[43] Mackness B, Durrington PN, Mackness MI (1999) Polymorphisms of Paraoxonase Genes and Low-Density Lipoprotein Lipid Peroxidation: Lancet 353:468-469.

[44] Gaidukov L, Tawfik DS (2005) High Affinity, Stability, and Lactonase Activity of Serum Paraoxonase PON1 Anchored on HDL With ApoA-I. Biochemistry 44:11843-11854.

[45] Jakubowski H (1997) Metabolism of Homocysteine Thiolactone in Human Cell Cultures. Possible Mechanism for Pathological Consequences of Elevated Homocysteine Levels. J. Biol. Chem. 272:1935-1942. 
[46] Jakubowski H, Zhang L, Bardeguez A, Aviv A (2000) Homocysteine Thiolactone and Protein Homocysteinylation in Human Endothelial Cells: Implications for Atherosclerosis. Circ. Res. 87: 45-51.

[47] Jakubowski H (2006) Pathophysiological Consequences of Homocysteine Excess. J. Nutr. 136:1741S-1749S.

[48] Jakubowski H (2004) Molecular Basis of Homocysteine Toxicity in Humans. Cell Mol. Life Sci. 61:470-487.

[49] Chwatko G, Jakubowski H (2005) The Determination of Homocysteine-Thiolactone in Human Plasma. Anal. Biochem. 337:271-277.

[50] Domagała TB, Łacinski M, Trzeciak WH, Mackness B, Mackness MI, Jakubowski H (2006) The Correlation of Homocysteine-Thiolactonase Activity of the Paraoxonase (PON1) Protein With Coronary Heart Disease Status. Cell Mol. Biol. (Noisy-le-grand) 52:3-9.

[51] Jarvik GP, Rozek LS, Brophy VH, Hatsukami TS, Richter RJ, Schellenberg GD, Furlong CE (2000) Paraoxonase (PON1) Phenotype is a Better Predictor of Vascular Disease Than is PON1192 or PON155 Genotype. Arterioscler. Thromb. Vasc. Biol. 20:2441-2447.

[52] Jarvik GP, Jampsa R, Richter RJ, Carlson CS, Rieder MJ, Nickerson DA, Furlong CE (2003) Novel Paraoxonase (PON1) Nonsense and Missense Mutations Predicted by Functional Genomic Assay of PON1 Status. Pharmacogenetics. 13:291-295.

[53] Mackness B, Davies GK, Turkie W, Lee E, Roberts DH, Hill E, Roberts C, Durrington PN, Mackness MI (2001) Paraoxonase Status in Coronary Heart Disease: Are Activity and Concentration More Important Than Genotype? Arterioscler. Thromb. Vasc. Biol. 21:1451-1457.

[54] Mackness B, Durrington P, McElduff P, Yarnell J, Azam N, Watt M, Mackness M (2003) Low Paraoxonase Activity Predicts Coronary Events in the Caerphilly Prospective Study. Circulation. 107:2775-2779.

[55] Mackness MI, Durrington PN, Mackness B (2004) The Role of Paraoxonase 1 Activity in Cardiovascular Disease: Potential for Therapeutic Intervention. Am. J. Cardiovasc. Drugs. 4:211-217.

[56] Bhattacharyya T, Nicholls SJ, Topol EJ, Zhang R, Yang X, Schmitt D, Fu X, Shao M, Brennan DM, Ellis SG, Allayee H, Lusis AJ, Hazen SL (2008) Relationship of Paraoxonase 1 (PON1) Gene Polymorphisms and Functional Activity With Systemic Oxidative Stress and Cardiovascular Risk. JAMA 299:1265-1276.

[57] Costa LG, Cole TB, Jarvik GP, Furlong CE (2003) Functional Genomics of the Paraoxonase (PON1) Polymorphisms: Effect on Pesticide Sensitivity, Cardiovascular Disease, and Drug Metabolism. Annu Rev. Med. 54:371-392.

[58] Richter RJ, Jarvik GP, Furlong CE (1999) Determination of Paraoxonase 1 (PON1) Status Without the Use of Toxic Organophosphate Substrates. Circ Cardiovasc Genet. 1:147152.

[59] Costa LG, Cole TB, Furlong CE. (2005) Paraoxonase (PON1): From Toxicology to Cardiovascular Medicine. Acta Biomed. Suppl 2:50-57. 
[60] Karabina SA, Lehner AN, Frank E, Parthasarathy S, Santanam N(2005) Oxidative Inactivation of Paraoxonase-Implications in Diabetes Mellitus and Atherosclerosis. Biochim. Biophys. Acta. 1725:213-221.

[61] Sozmen EY, Sagin FG, Kayikcioglu M, Sozmen B (2008) Oxidative Stress \& Antioxidants and PON1 in Health and Disease. In: Mackness B, Mackness M, Aviram M, Paragh G, editors. The Paraoxonases: Their Role in Disease Development and Xenobiotic Metabolism. Dordrecht:Springer.pp 61-73.

[62] Camps J, Marsillach J, Joven J (2009) The Paraoxonases: Role in Human Diseases and Methodological Difficulties in Measurement.Crit. Rev. Clin. Lab. Sci. 46:83-106.

[63] Shih DM, Lusis AJ (2009) The Roles of PON1 and PON2 in Cardiovascular Disease and Innate Immunity. Curr. Opin. Lipidol. 20: 288-292.

[64] Ng CJ, N. Bourquard N, Grijalva V, Hama S, Shih DM, Navab M, Fogelman AM, Lusis AJ, Young S, Reddy ST (2006) Paraoxonase-2 Deficiency Aggravates Atherosclerosis in Mice Despite Lower Apolipoprotein-B-containing Lipoproteins: Anti-atherogenic Role for Paraoxonase-2. J. Biol. Chem. 281:29491-29500.

[65] Ng CJ, Hama SY, Bourquard N, Navab M, Reddy ST (2006) Adenovirus Mediated Expression of Human Paraoxonase 2 Protects Against the Development of Atherosclerosis in Apolipoprotein E-deficient mice. Mol. Genet. Metab. 89:368-373.

[66] Fortunato G, Di Taranto MD, Bracale UM, Del Guercio L, Carbone F, Mazzaccara C, Morgante A, D'Armiento FP, D'Armiento M, Porcellini M, sacchetti L, Bracale G, Salvatore F (2008) Decreased Paraoxonase-2 Expression in Human Carotids During the Progression of Atherosclerosis. Arterioscler. Thromb. Vasc. Biol. 28:594-600.

[67] Horke S, Witte I, Wilgenbus P, Kruger M, Strand D, Forstermann U (2007) Paraoxonase2 Reduces Oxidative Stress in Vascular Cells and Decreases Endoplasmic Reticulum Stress-induced Caspase Activation. Circulation. 115:2055-2064.

[68] Devarajan A, Bourquard N, Hama S, Navab M, grijalva VR, Morvardi S, Clarke CF, Vergnes L, Reue K, Teiber JF, Reddy ST (2011) Paraoxonase 2 Deficiency Alters Mitochondrial Function and Exacerbates the Development of Atherosclerosis. Antioxid. Redox Signal. 14:341-351.

[69] Altenhöfer S, Witte I, Teiber JF, Wilgenbus P, Pautz A, Li H, Daiber A, Witan H, Clement AM, Förstermann U, Horke S (2010) One Enzyme, Two Functions: PON2 Prevents Mitochondrial Superoxide Formation and Apoptosis Indenpendent From its Lactonase Activity. J. Biol. Chem. 285:24398-24403.

[70] Rosenblat M, Draganov D, Watson CE, Bisgaier CL, La Du BN, Aviram M (2003) Mouse Macrophage Paraoxonase 2 Activity is Increased Whereas Cellular Paraoxonase 3 Activity is Decreased Under Oxidative Stress. Arterioscler. Thromb. Vasc. Biol. 23:468474.

[71] Shiner M., B. Fuhrman B, Aviram M (2004) Paraoxonase 2 (PON2) Expression is Upregulated via a Reduced-nicotinamide-adenine-dinucleotide-phosphate (NADPH)oxidase-dependent Mechanism During Monocytes Differentiation Into Macrophages. Free Radic. Biol. Med. 37: 2052-2063. 
[72] Shiner M, Fuhrman B, Aviram M (2006) A Biphasic U-shape Effect of Cellular Oxidative Stress on the Macrophage Anti-oxidant Paraoxonase 2 (PON2) Enzymatic Activity. Biochem. Biophys. Res. Commun. 349:1094-1099.

[73] Rosenblat M, Hayek T, Hussein K, Aviram M (2004) Decreased Macrophage Paraoxonase 2 Expression in Patients with Hypercholesterolemia is the Result of Their Increased Cellular Cholesterol Content: Effect of Atorvastatin Therapy. Arterioscler. Thromb. Vasc. Biol. 24:175-180.

[74] Levy E, Trudel K, Bendayan M, Seidman EG, Delvin E, Lavoie JC, Precourt LP, Amre D, Sinnett D (2007) Biological Role, Protein Expression, Subcellular Localization and Oxidative Stress Response of Paraoxonase 2 in the Intestine of Humans and Rats. Am. J. Physiol. Gastrointest. Liver Physiol. 293:G1252-G1261.

[75] Li WF., Costa LG, Furlong CE (1993) Serum Paraoxonase Status: a Major Factor in Determining Resistance to Organophosphates. J. Toxicol. Environ. Health. 40:337-346.

[76] Clarimon J, Eerola J, Hellstörm O, Tienari PJ, Singleton A (2004) Paraoxonase 1 (PON1) Gene Polymorphisms and Parkinson's Disease in a Finnish Population. Neurosci. Lett. 367:168-170.

[77] Leus FR, Zwart M, Kastelein JJP, Voorbij HAM (2001) PON2 Gene Variants are Associated With Clinical Manifestations of Cardiovascular Disease in Familial Hypercholesterolemia Patients. Atherosclerosis. 154:641-649.

[78] Parra S, Alonso-Villaverde C, Coll B, Ferré N, Marsillach J, Aragonès G, Mackness M, Mackness B, Masana L, Joven J, Camps J (2007) Serum Paraoxonase-1 Activity and Concentration are Influenced by Human Immunodeficiency Virus Infection. Atherosclerosis. 194:175-181.

[79] Sardo MA, Campo S, Bonaiuto M, Bonaiuto A, Saitta C, Trimarchi G, Castaldo M, Bitto A, Cinquegrani M, Saitta A (2005) Antioxidant Effect of Atorvastatin is Independent of PON1 Gene T(-107)C, Q192R and L55M Polymorphisms in Hypercholesterolaemic Patients. Curr. Med. Res. Opin. 21:777-784.

[80] O'Leary KA, Edwards RJ, Town MM, Boobis AR (2005) Genetic and Other Sources of Variation in the Activity of Serum Paraoxonase/Diazoxonase in Humans: Consequences for Risk From Exposure to Diazinon. Pharmacogenet. Genomics 15:51-60.

[81] Aynacioglu AS, Cascorbi I, Mrozikiewich PM, Nacak M, Tapanyigit EE, Roots I (1999) Paraoxonase 1 Mutations in a Turkish Population. Toxico.L. Appl. Pharmacol. 157:174177.

[82] Grdić M, Barišić K, Rumora L, Salamunić I, Tadijanović M, Žanić-Grubišić T, Pšikalova R, Fleger-Meštrić Z, Juretić D (2008) Genetic Frequencies of Paraoxonase 1 Gene Polymorphisms in Croatian Population. Croat. Chem. Acta 81:105-111.

[83] Flekač M, Škrha J, Zídková K, Lacinová Z, Hilgertová J (2008) Paraoxonase 1 Gene Polymorphisms and Enzyme Activities in Diabetes Mellitus. Physiol Res. 57:717-726.

[84] Pejin-Grubiša I, Buzadžic I, Jankovic-Oreščanin B, Barjaktarović-Vučinić N (2010) Distribution of Paraoxonase 1 Coding Region Polymorphisms in Serbian Population. Genetika 42:235-247. 
[85] Gupta N, Singh S, Maturu N, Sharma YP, Gill KD (2011) Paraoxonase 1 Polymorphisms, Haplotypes and Activity in Predicting CAD Risk in North-West Indian Punjabis. PloS One 6(5).

Available:http://www.plosone.org/article/info\%3Adoi\%2F10.1371\%2Fjournal.pone.0017 805. Accessed 2011 May 24

[86] Suehiro T, Nakamura T, Inoue M, Shiinoki T, Ikeda Y, Kumon Y, Shindo M, Tanaka H, Hashimoto K (2000) A Polymorphism Upstream From the Human Paraoxonase (PON1) Gene and its Asociation With PON1 Expression. Atherosclerosis. 150:295-298.

[87] Hong SH, Song J, Min WK, Kim JQ (2001) Genetic Variations of the Paraoxonase Gene in Patients With Coronary Artery Disease. Clin. Biochem. 34:475-481.

[88] Mohamed Ali S, Chia SE (2008) Interethnic Variability of Plasma Paraoxonase (PON1) Activity Towards Organophosphates and PON1 Polymorphism Among Asian Populations-a Short Review. Ind. Health 46:309-317.

[89] Zhang F, Liu HW, Fan P, Bai H, Song Q (2011) The -108 C/T Polymorphism in Paraoxonase 1 Gene in Chinese Patients With Polycystic Ovary Syndrome. Sichuan Da Xue Xue Bao Yi Xue Ban. 42:24-28.

[90] Sepahvand F, Rahimi-Moghaddam P, Shafiei M, Ghaffari SM, Rostam-Shirazi M, Mahmoudian M (2007) Frequency of Paraoxonase 192/55 Polymorphism in an Iranian Population. J. Toxicol. Environ. Health 70:1125-1129.

[91] McKeown-Eyssen C, Baines C, Cole DEC, Riley N, Tyndale RF, Marshall L, Jazmaji V (2004) Case-Control Study of Genotypes in Multiple Chemical Sensitivity: CYP2D6, NAT1, NAT2, PON1, PON2 and MTHFR. Int. J. Epidem. 33:1-8.

[92] Chen J, Kumar M, Chen W, Berkowitz G, wetmur JG (2003) Increased Influence of Genetic Variation on PON1 Activity in Neonates. Environ. Health Perspect. 111:14031409.

[93] Santos NPC, Santos AKCR, Santos SEB (2005) Frequency of the Q192R and L55M Polymorphisms of the Human Serum Paraoxonase Gene (PON1) in Ten Amazonian Amerindian Tribes. Genet. Mol. Biol. 28:36-39.

[94] Rojas-Garcia AE, Solis-Heredia MJ, Pina-Guzman B, Vega L, LopezCarrillo L, Quintanilla-Vega B (2005) Genetic Polymorphisms and Activity of PON1 in a Mexican Population. Toxicol. Appl. Pharmacol. 205:282-289.

[95] Cataño HC, Cueva JL, Cardenas AM, Izaguirre V, Zavaleta AI, Carranca E, Hernández AF (2006) Distribution of Paraoxonase-1 Gene Polymorphisms and Enzyme Activity in a Peruvian Population. Environ. Molecul. Mutagen. 47:699-706.

[96] Scacchi R, Corbo RM, Rickards O, De Stefano GF (2003) New Data on the World Distribution of Paraoxonase (PON1Gln192 $\rightarrow$ Arg) Gene Frequencies. Hum. Biol. 75:365373.

[97] El-Fasakhany FM, El-Segeaya O, Alahwal L, Abu Al-Nooman S (2007) Paraoxonase 1 Activity and Paraoxonase 192 Gene Polymorphism in Non Insulin Dependent Diabetes Mellitus Patients Among Egyptian Population. Tanta. Med. Scien. J. 2:68-77. 